Tillmans, ${ }^{13}$ Whitman ${ }^{14}$ and Monks ${ }^{15}$ ), is unsound, because the groove of the fibula is not designed for the safe play of the tendons, is only a small part of the tendon trough; it is shallow normally, and we cannot improve on nature's normal forms.

On the other hand, the correct surgical treatment for dislocation of the peroneal tendons is the surgical reconstruction of the external annular ligament (as done and described by Kraske ${ }^{16}$ ), and keeping the foot until healing takes place in such a position that the calcaneo-fibular ligament is relaxed. This position is that between extension and flexion.

\section{A CASE OF PSEUDO-HERMAPHRODITISM.*}

BY William L. HaRris, M.D., PROVIdence, R. I., Surgeon to St. Joseph's Hospital.

The crowning infamy of the Roman Emperor Nero's career of degeneracy was, according to the historian Suetonius, his marriage with the boy Sporus. ${ }^{1}$ It was a very public affair and well advertised throughout the city. Some sort of operation was performed on the boy and the historian says an attempt was made to alter him into a woman. Even in the terror of the tyrant's reign the wags of the city gave currency to the observation that Nero's father would have done well for mankind had he taken unto himself such a wife.

This well-known story from ancient history is too gossipy, also too lacking in details, for us to hazard a guess as to the operation the crude surgery of the years between 60 and 70 A.D. was capable of performing, or even as to the physical condition of the boy Sporus. But it has been suggested to me by the subject which shall be my theme this evening and the part $\mathrm{I}$. once played quite unwittingly and unwillingly, and against my protest, in the mating of two males.

It is now some years ago since I was called one night towards midnight to a patient, a girl some seventeen years old, who, I was told, was " having a fit." Her family were people in very comfortable circumstances and patients of mine. I hastened to the call and found them quite unprepared for my sudden arrival. The mother pointed out the room of the sick girl, but asked me to wait till she herself was fully dressed. Quite absent mindedly I disregarded the woman's injunction and pushed my way in the dark to the half open door. It would be difficult to describe the shock I received as I entered. The girl was lying on the bed evidently unconscious, but in the writhings produced by the convulsion she was almost completely uncovered; and my attention was immediately attracted by the presence of an unusually developed penis some six inches long and perhaps three inches in circumference. But my curiosity to examine more closely this unusual

13 Text-book of Surgery. N. Y., 1899, p. 510

14 Treatise on Orthopedic Surgery. N. Y 1901, p. 555.

is International Text-book of Surgery. Phila., 1900, p. 758 .

16 Centralbl. f. Chir., No. 24, 1895 .

* Read before the Fall River Medical Society, Dec. 8, 1908. 1 See Suetonius, chapter 27. condition of affairs was cut short by the appearance of the mother, now thoroughly embarrassed and crestfallen that what was evidently a family secret had been exposed to me. The patient's condition was not serious and yielded to the usual treatment. But afterwards I could not refrain from discussing with her parents the extraordinary phenomenon displayed by this alleged girl.

From them I discovered that when the child was born there was evident a small, imperforate protrusion in the genital region which the attending physician described as an enlargement of the clitoris. Immediately below its base and in the median line there was a small opening about one inch long, through which the child voided urine. The physician's explanation was accepted and in a few days the infant was named after a female relative and entered on the rôle of a girl. With the growth of the girl, the mysterious protuberance also grew. The physicians who were consulted always agreed with the first and allayed the fears of the parents. When the child was ten, the mother several times noticed that at night this mass would become quite erect, but, secure in the consultations of earlier years, she kept her knowledge to herself and consulted no further.

The child grew up as a girl and entered into the games of girls, being very fond of dolls. Household work she abominated, as, for that matter, many a girl of undoubted sex abominates it nowadays. Her companions, especially as she grew older, were not those of her own age but older women who were very fond of her and with whom she sometimes stayed over night. Her features were somewhat coarse, her voice deep and harsh, her upper lip and chin had a considerable growth of black hair, while the hair of her head was decidedly coarse and abundant. She had two sisters younger than herself, but felt a marked aversion to helping her mother in caring for them. At fifteen both parents remarked a great change in her. She had been attending school till then and was considered a good scholar. But at that age she begged so hard to be allowed to go to work that her parents consented and she was soon employed in an industrial establishment. Her ambition was to own a bicycle and she soon had saved enough money to buy one. She speedily became proficient in its use and her performances on it were the talk of the neighborhood. She could ride the fastest and the farthest of any of her companions.

At seventeen she was seized with her first attack of epilepsy. In what was probably the third or fourth attack I was summoned.

All that I heard and saw whetted my appetite to know more about the case, which was unique in my experience. The text and reference books mention such cases but sparingly and in general practice they come seldom if ever. At my earnest request to determine if possible the sex of the patient, the parents consented and Dr. J. W. Mitchell; of Providence, and I made a careful examination under ether. We found the patient fairly well nourished, with muscles well developed. There was no increase of fat or glandular tissue 
in the mammary region. "She" was 5 feet 8 inches tall and weighed 137 pounds. Her legs and thighs were firm and muscular, looking like a boy's rather than a girl's. The pelvic bones were small, the hips narrow. About the symphysis pubis was a small amount of hair and immediately below it hung what was evidently a moderately developed penis which when flaccid measured about three inches in circumference and nearly four inches in length. There was no scrotum, the inguinal rings being tightly closed and no evidence of spermatic cord or of testicles. At the base of this organ, posteriorly and in the median line, there was an opening about one and one half inches long, lined with a pink mucous membrane which was thrown into several longitudinal folds on either side. An instrument passed into this opening the distance of two inches entered the bladder. The index finger could be inserted with difficulty to the extent of three fourths of an inch. On either side of this opening there was increase of cellular tissue, suggesting somewhat the labia majora. On the surrounding skin there were a few coarse hairs. Rectal examination failed to discover a uterus, nor did examination, bi-manually with the left hand in the rectum and the right pressing through the abdominal wall so that the fingers of both hands met, yield any positive result.

Two distinct cavernous bodies could be made out in the penis as also a third spongy body. Crowning all was a round mass suggestive of a glans penis, on one side of which was a fairly welldeveloped foreskin. This mass became greatly congested during the examination as a result of reflex irritation and increased to three or four times its normal size. Dr. Mitchell agreed with me that everything suggested that our patient was of the male sex, a definite case of androgyna. We informed the parents that they should change the young person's dress at once. The laws do not permit a male to masquerade as a female nor contrariwise. The wisdom of such legislation may not be disputed, though its hardship in such a case as this is evident. Here was a child always brought up as a girl and associating with girls, suddenly, without explanation, to be declared a boy. Not to speak of the ridicule which such a procedure would engender even among the persons intimately associated with the family, there was wider publicity and scandal to be feared either from the interference of inquisitive police authorities or the maudlin curiosity of professional newsmongers. The humiliation of such an exposure was beyond question. The parents were reasonable but the difficulties seemed to them insurmountable. We offered them the alternative of either leaving Providence and going elsewhere, changing the dress of their child with their change of home, or, if they remained where they were, the removal by surgical operation of the useless organ.

I secretly hoped that they would have chosen the former, but to my chagrin they chose the latter. Now it is always a delicate matter to counsel the amputation of these organs, no matter how rudimentary. In fact, both the theory and the practice of surgery as known to us are strongly opposed to such amputations; but, on the other hand, if there are cases when for the health of a patient it is both lawful and commendable to remove a uterus or the testicles, I see no good reason why there should be any hesitation in removing such a perfectly useless, cmbarrassing abnormality. Nay, my experience in this case rather furnished me, quite unexpectedly I must confess, with a good reason for performing this operation, for the epilepsy which had begun to manifest itself disappeared immediatcly and did not return until a subsequent period, and then through an undoubted provocation of which I will presently speak. Dr. Mitchell kindly offered to assist me at the operation, which took place a few days later. When the patient was etherized I removed the mass, employing a racquet incision as in the amputation of a finger. As soon as the incision was made, the mass became greatly distended from congestion, a condition which facilitated my dissection, and I carefully cut down on either side until I had reached its capsule. Each cavernous body in the mass terminated in a crus which was attached to the descending ramus of either pubic bone. As I pulled it clear from its surroundings, I noticed two thin cords, the size of ordinary twine, which came from bchind the inguinal rings and which terminated in a small mass the size of a lima bean. Their position and character, in spite of their lack of resemblance to normal organs, suggested to me at once that I was in the presence of rudimentary spermatic cords and testicles. I closed the opening with a few interrupted sutures and in a few days my patient was again about, apparently none the worse for the experience.

Naturally I felt an interest in the subsequent health and history of this unusual patient. The psychology of sex is a large subject, but one that is forced, one way or another, upon the attention of even the most unobservant member of the medieal profession. But this unsexed patient had also its psychology. It was not that of a girl, and it turned out eventually to resemble closely that of a sexual pervert. The mother kept me posted on what she considered the changes of character or habit in her child. She informed me that she had received an ultimatum from my patient that henceforth there must be no question of doing household work, neither washing of dishes nor sweeping of floors nor minding of children. Henceforth only the life out of doors on the wheel or anywhere but home. Many an evening, "she" - I use the pronoun with hesitation but in accordance with the legal status of my patient, - spent with the older women, with whom she had always a fast friendship. For the company of young men "she" manifested no desire. About a year after the operation she "escaped" from home through her bedroom window, descending by means of sheets, tied together in the most approved dime novel-fashion. The customary note was on the bureau, bidding the grand farewell to home and mother. As nobody expected the 
escapadc, and the doors were not nailed up, the choice of the chamber window and the shects tied together was entirely voluntary. There was no cavalier in waiting and the moon, so far as noted, was not shaded by a favoring cloud. But the parents in the old-fashioned way were alarmed and were minded to start a hue and cry for their child. I counseled waiting a little while, and shortly their patience was rewarded by discovering that the object of their alarm had found shelter not very far away from their home. The absence of search possibly disappointed her, for before long she returned quite crestfallen and seemed more than ever willing to do what she was bidden, even the work about the house. During all this time, cxtending over several years, there was no recurrence of epilepsy. Her health was excellent; her spirits good. Then, as I learned afterwards, a very amiable young man became interested in her. His feelings speedily ripened into love, and to the consternation of her parents he demanded her hand in marriage. Again I was consulted and I resolved to talk openly to the putative girl whose charms were playing havoc with a worthy young man's heart. My frank exposure of her condition seemed to convince her that it was her duty to bid her suitor begone, or at least I deceived myself into thinking that she was convinced. But I found out that if convinced, her convictions soon fled before the importunity of her admirer. Then, with her parents' permission, I sent for the young man. I very plainly told him the condition of affairs, but the more I said the more the fire of his love burned brightly. "Doctor," said he, "what you tell me makes me love her all the more. She is one of the best and purest of women, and if what you say be true then she needs a protector and I shall devote myself to making her happy." "But," I interposed, " it is not a "she' you are courting, it is a man! Do you want to marry a man?" Evidently he did. But some one suggested that after all it was not certain that she was not a woman, and an exploratory laparotomy in search of a uterus was broached. To please them I operated, but found neither uterus nor broad ligaments nor ovaries; no sexual organs of any kind.

The upshot of the matter, however, was a runaway marriage. The result of the marriage was a recurrence of the epileptic attacks which had been absent four years. Sexual desire, however unreasonable and unfounded, became a mania in this developed pervert. Epilepsy made her an invalid and presently impaired her mental condition so seriously that she needed to be constantly watched. The husband, devoted as ever, was persuaded to live apart, and immediately the patient improved. But with his return and the demands of his "spouse," the sickness returned more violently than ever, so that finally she had to be committed to an institution for the insane to prevent her from doing harm to herself and family. There she improved enough to be dismissed after a few months and to come back to her husband, this time inoculated with syphilis; and just there I leave them, the one the victim of a malformation for which he was not responsible, the other the victim of his own blindness and madness which, in spite of warning and advice, made him elect as his partner an abnormal being and waste on a monstrosity the honorable sentiments which in normal circumstances would have won for him a happy home. One thing I thought I discovered in this case, and that is, that if this abnormal being had not been disturbed by attempts at sexual gratification, he would, very likely, have escaped the violent epilepsy of which he became the hopeless victim.

No other case resembling this have I ever met with in my practice nor heard of from my associates. The scientific interest on the one hand in such abnormalities is great, but the human side of them has its poignancy, - the distress and shame of parents, on the other hand, and often the lack of shame of these physically lawless creatures who are victims almost certainly foredoomed to catastrophe. The vain imaginings of Greek and Roman artists of the perfect hermaphrodite, with the potency of both sexes in one person, find no correspondence in the world of fact save these poor maimed specimens, fortunately rare, whose obscure sex, so far from denoting a perfection of any kind, make them rather victims of the curious, or, like Nero's Sporus, of the degenerate, and in any case types of the sexually impotent.

\section{A STUDY ON HAND STERILIZATION.}

By ChaRles GREENe CUMSTON, M.D., Boston, Mass.

(Concluded from No. 11, p. 340.)

THE preparation of soap for hand disinfection is of great importance and many are the formulæ which have been given. Mention has already been made of Schleich's marble dust soap, and all that I would say is that the marble dust rubs off the upper epidermic scales and smooths the skin without injuring it. The use of this soap is particularly adapted to rough hands, which are naturally extremely difficult to sterilize. Callous portions of the skin can be cleaned in a short space of time and are rendered soft and smooth so that the action of the antiseptic is not interfered with. Other forms of soap containing different kinds of sand have been recommended from time to time, but space forbids referring to them here. A manufactured soap called Ubrigin has been recommended by Van Nissen, its mechanical action bcing ascribed to the vegetable fiber it contains. This does not become decomposed, is impregnated with boracic acid and consequently the fine distribution of the vegetable fiber results in a penetration into the deeper pores of the skin than is possible with either brush or pumice. It is also said that it does not injure the skin. None of these soaps have any direct bacteriacidal power, but it is of importance to recall the fact that most soaps may be considered germ free and that the development and multiplying of bacteria does not occur in any of them. 